\title{
DESKRIPSI PEMAHAMAN KONSEP DALAM \\ MENYELESAIKAN SOAL TEOREMA PHYTAGORAS \\ DITINJAU DARI GAYA KOGNITIF PADA SISWA KELAS VIII SMP NEGERI 3 CAMBA
}

\author{
Ilhamuddin ${ }^{1 *}$ \\ Muh. Ridwan ${ }^{2}$ \\ Muhammad Darwis M. ${ }^{3}$ \\ ${ }^{1,2}$ Universitas Muhammadiyah Makassar, Makassar, Indonesia \\ ${ }^{3}$ Universitas Negeri Makassar, Makassar, Indonesia \\ ilhamuddin@unismuh.ac.id ${ }^{1^{*}}$ \\ ,muhridwan.math16@gmail.com ${ }^{2}$ \\ darwisfamily7@gmail.com ${ }^{3}$
}

\begin{abstract}
Abstrak
Tujuan penelitian untuk mendeskripsikan pemahaman konsep dalam menyelesaikan soal teorema Phytagoras ditinjau dari gaya kognitif pada siswa kelas VIII SMP Negeri 3 Camba. Penelitian ini merupakan penelitian deskriptif dengan pendekatan kualitatif. Ada 4 subjek dalam penelitian ini, 2 subjek Field Dependent (FD) dan 2 subjek Field Independent (FI) yang dipilih berdasarkan hasil tes Group Embedded Figure Test (GEFT). Soal tes pemahaman konsep yang diajukan terdiri dari 3 nomor. Konsep-konsep yang dimaksud adalah konsep-konsep yang digunakan dalam menyelesaikan soal teorema Phytagoras. Pada soal nomor 1 terdapat 3 konsep yang diamati yaitu konsep segitiga (K1), konsep segitiga siku-siku (K2), konsep sudut dan sisi (K3). Indikator yang digunakan dalam penelitian ini adalah menyatakan ulang sebuah konsep (I1), memberi contoh dan bukan contoh dari konsep (I2). Hasil yang diperoleh subjek Field Dependent (FD) untuk S1FD konsep K1 dan K2 semua indikator terpenuhi, dan untuk konsep K3 hanya indikator $\mathrm{I}_{1}$ terpenuhi. Adapun, untuk S2FD konsep K1 hanya indikator $\mathrm{I}_{1}$ terpenuhi, untuk konsep $\mathrm{K} 2$ semua indikator terpenuhi, dan untuk konsep K3 tidak ada indikator terpenuhi. Hasil yang diperoleh subjek Field Independent (FI) untuk S1FI konsep K1 dan K2 semua indikator terpenuhi, dan untuk konsep K3 hanya indikator $\mathrm{I}_{1}$ terpenuhi. Adapun, untuk S2FI konsep K1 dan K2 semua indikator terpenuhi, dan untuk konsep K3 hanya indikator $\mathrm{I}_{1}$ terpenuhi.
\end{abstract}

Kata Kunci: Pemahaman Konsep, Gaya Kognitif, Teorema Phytagoras

Diterbitkan Oleh:

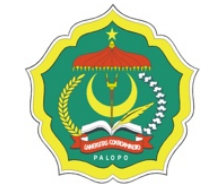

\author{
Fakultas Sains \\ Program Studi Matematika \\ Universitas Cokroaminoto Palopo
}

Copyright (C) 2021 The Author (s)

This article is licensed under CC BY 4.0 License

\section{(cc) $\mathrm{BY}$}




\section{DESKRIPSI PEMAHAMAN KONSEP DALAM MENYELESAIKAN SOAL TEOREMA PHYTAGORAS DITINJAU DARI GAYA KOGNITIF PADA SISWA KELAS VIII SMP NEGERI 3 CAMBA}

\section{Pendahuluan}

Salah satu ilmu pengetahuan dalam dunia pendidikan yang sangat penting dipelajari bagi siswa yaitu matematika. Matematika adalah suatu bidang studi yang mempunyai objek bersifat abstrak, sehingga untuk mempelajari matematika dibutuhkan pemikiran yang jelas, logis, kritis, dan sistematis sesuai dengan logika. Dengan demikian, kegiatan pembelajaran yang dilaksanakan akan mencapai tujuan pembelajaran yang diharapkan. Adapun tujuan utama mempelajari matematika berdasarkan Permendiknas No. 22 tahun 2006 salah satunya yaitu memiliki kemampuan pemahaman konsep matematika, menjelaskan hubungan antar konsep, serta mengaplikasikan konsep secara luwes, akurat, dan tepat.

Ketika mempelajari matematika, konsep harus dipahami terlebih dahulu sehingga dapat dengan mudah menggunakan kemampuan tersebut dalam menyelesaikan soal-soal yang ada. Akan tetapi, jika pemahaman konsep siswa rendah tentunya siswa akan menghadapi kendala dalam menyelesaikan soal-soal karena penyelesaian soal matematika sangat bergantung dengan pemahaman konsep. Menurut Sanjaya (Herwandi, 2017: 26), pemahaman konsep adalah kemampuan siswa yang berupa penguasaan sejumlah materi pelajaran, dimana siswa tidak sekedar mengetahui atau mengingat sejumlah konsep-konsep yang dibicarakan, tetapi dapat menyatakan kembali dalam bentuk lain, dapat menginterpretasi data dan dapat mengaplikasikan konsep-konsep tersebut. Oleh karena itu, siswa dikatakan telah memahami konsep apabila ia mampu mendefinisikan ulang suatu konsep baik dalam bentuk lisan maupun tulisan kepada orang lain, mampu membuat generalisasi dari konsep yang dipelajari, dan menggunakan konsep tersebut. Indikator pemahaman konsep yang digunakan dalam penelitian ini adalah sebagai berikut (Lihat Tabel 1):

Tabel 1. Indikator Pemahaman Konsep

\begin{tabular}{clrl}
\hline NO & \multicolumn{1}{c}{ Indikator } & \multicolumn{1}{c}{ Indikator Kemampuan } \\
\hline 1 & $\begin{array}{l}\text { Menyatakan ulang } \\
\text { sebuah konsep }\end{array}$ & $\begin{array}{l}\text { Siswa mampu untuk mendefinisikan } \\
\text { konsep dengan menggunakan kata-kata } \\
\text { atau kalimatnya sendiri. }\end{array}$ \\
2 & $\begin{array}{l}\text { Memberi contoh dan } \\
\text { bukan contoh dari } \\
\text { konsep }\end{array}$ & $\begin{array}{l}\text { Siswa mampu membedakan contoh atau } \\
\text { bukan contoh dari suatu konsep yang } \\
\text { telah dipelajari }\end{array}$ \\
Mengaplikasikan & Siswa mampu menggunakan konsep \\
konsep & serta prosedur dalam menyelesaikan \\
& suatu soal dengan benar dan tepat.
\end{tabular}


Adapun materi matematika SMP kelas VIII yang memerlukan pemahaman konsep yang baik salah satunya ialah teorema Phytagoras. Teorema Phytagoras adalah sebuah dalil yang di pakai dalam mencari panjang sisi dari suatu segitiga siku-siku. Meskipun cuman mencari panjang sisi dari suatu segitiga siku-siku, akan tetapi siswa sering mengalami kendala dalam hal menyelesaikan soal-soal teorema Phytagoras. Hal ini ditemui juga peneliti pada saat observasi lapangan di SMP Negeri 3 Camba pada tanggal 7 Oktober 2019, yaitu sebagian besar siswa kurang mampu dalam memilih prosedur atau operasi yang sesuai dalam menyelesaikan soal-soal teorema Phytagoras. Selain itu, kemampuan siswa dalam membuat kesimpulan materi seperti mendefinisikan dan menyebutkan contoh lain dari konsep yang dibicarakan juga masih mengalami kesulitan, serta terdapat siswa yang kurang memahami maksud dari soal-soal teorema Phytagoras yang berkaitan dengan kehidupan sehari-hari. Akibatnya, hasil ulangan teorema Phytagoras pada siswa kelas VIII-A menunjukkan persentase siswa yang belum tuntas atau tidak mencapai KKM adalah 70\%. KKM yang diterapkan pihak sekolah pada mata pelajaran matematika kelas VIII yaitu 74. Hal ini menandakan bahwa pemahaman konsep dalam menyelesaikan soal teorema Phytagoras pada siswa belum baik walaupun ada beberapa siswa yang pemahaman konsepnya sudah baik.

Pada saat menyelesaikan soal teorema Phytagoras, setiap siswa memiliki karakteristik khas yang berbeda-beda dari siswa lain. Perbedaan karakteristik khas tersebut dapat diungkap oleh tipe-tipe kognitif yang dikenal dengan gaya kognitif. Menurut Nasution (Trinovita, 2017: 32) mendefinisikan gaya kognitif sebagai cara konsisten yang dilakukan oleh seorang siswa dalam menangkap stimulus atau informasi, cara mengingat, berpikir, dan memecahkan soal. Adapun menurut Messick (Kozhevnikov, 2006: 464) menyatakan bahwa "Cognitive style are stable attitudes, preferences or habitual strategies determining a person's typical modes of perceiving, remembering, thinking and problem solving”. Gaya kognitif merupakan sikap stabil, pilihan atau menentukan strategi kebiasaan seseorang memahami cara-cara yang khas, mengingat, berpikir dan pemecahan masalah.. Oleh karena itu, guru perlu memberikan perhatian khusus terhadap gaya kognitif yang dimiliki setiap siswa agar proses pembelajaran dapat berlansung dengan baik.

Ditinjau dari ranah psikologis, gaya kognitif terdiri atas Field Dependent (FD) dan Field Independent (FI) (Witkin, dkk., 1977: 8). Untuk lebih jelasnya, Rahman (Trinovita, 2017: 35) menyatakan implikasi gaya kognitif berdasarkan perbedaan psikologis siswa dalam pembelajaran matematika adalah sebagai berikut: (1) siswa yang memiliki gaya kognitif Field Dependent cenderung memilih belajar matematika secara kelompok dan sesering mungkin berinteraksi dengan guru, memerlukan penguatan yang bersifat ekstrinsik dan mereka akan 
bekerja kalau ada tuntunan guru serta motivasi yang tinggi berupa pujian dan dorongan; dan (2) siswa yang memiliki gaya kognitif Field Independent cenderung memilih belajar matematika secara individual, merespon dengan baik, dan lebih independent. Di samping itu mereka dapat mencapai tujuan dengan motivasi intrinsik dan cenderung bekerja untuk memenuhi tujuan belajarnya. Meskipun gaya kognitif dibedakan menjadi dua, tetapi setiap siswa yang bergaya kognitif Field Dependent (FD) dan siswa bergaya kognitif Field Independent (FI) memiliki kelemahan dan kelebihan dalam bidangnya. Perbedaan gaya kognitif setiap siswa yang berbeda-beda ini tentu akan memberikan pengaruh yang berbeda pula terhadap pemahaman konsep matematika siswa.

Berdasarkan uraian latar belakang, peneliti tertarik melakukan penelitian untuk mengetahui bagaimana deskripsi pemahaman konsep dalam menyelesaikan soal teorema Phytagoras ditinjau dari gaya kognitif pada kelas VIII SMP Negeri 3 Camba?

\section{Metode Penelitian}

Jenis penelitian ini merupakan penelitian deskriptif dengan pendekatan kualitatif. Data pada penelitian ini terdiri dari data kualitatif yang selanjutnya dideskripsikan berupa kata-kata tertulis atau uraian dari subjek penelitian untuk mengetahui secara mendalam tentang pemahaman konsep dalam menyelesaikan soal teorema Phytagoras ditinjau dari gaya kognitif pada kelas VIII SMP Negeri 3 Camba. Lokasi pada penelitian ini adalah SMP Negeri 3 Camba. Subjek dalam penelitian ini ialah siswa kelas VIII SMP Negeri 3 Camba. Pemilihan kelas subjek dilakukan pada satu kelas dengan teknik purposive sampling yaitu kelas VIII.B. Berdasarkan data skor GEFT siswa maka dipilih 4 subjek penelitian masing-masing 2 orang siswa yang bergaya kognitif Field Dependent (FD) dan 2 orang siswa bergaya kognitif Field Independent (FI). Pemilihan subjek ini mengacu pada skor GEFT yang diperoleh setiap siswa, serta pertimbangan subjek mampu mengemukakan pendapatnya dengan baik serta bersedia mengikuti seluruh proses pengumpulan data pada penelitian ini. Adapun subjek yang terpilih adalah sebagai berikut.

Tabel 2. Subjek Terpilih

\begin{tabular}{cclcc}
\hline No & $\begin{array}{c}\text { Inisial } \\
\text { Siswa }\end{array}$ & $\begin{array}{c}\text { Jenis } \\
\text { Gaya Kognitif }\end{array}$ & $\begin{array}{c}\text { Skor } \\
\text { GEFT }\end{array}$ & $\begin{array}{c}\text { Kode Subjek dengan Gaya } \\
\text { Kognitif }\end{array}$ \\
\hline 1 & AH & Field & 5 & S1FD \\
2 & SZR & Dependent & & S2FD \\
3 & SM & Field & 18 & S1FI \\
4 & SR & Independent & 18 & S2FI \\
\hline
\end{tabular}


Pengumpulan data pada penelitian ini dilakukan dengan teknik Group Embedded Figure Test (GEFT), tes pemahaman konsep dan wawancara. Teknik tes GEFT dalam penelitian ini merupakan cara pengumpulan data dengan cara memberikan serangkaian tugas berupa tes perseptual yang diberikan kepada seluruh siswa kelas subjek terpilih. Siswa diminta mencari bentuk sederhana yang terdapat pada gambar rumit kemudian menebalkannya dengan pulpen. Teknik tes pemahaman konsep dalam penelitian ini merupakan cara pengumpulan data dengan cara memberikan serangkaian tugas berupa tes tertulis berbentuk uraian dengan materi teorema Phytagoras yang diberikan kepada subjek yang diteliti agar mendapat suatu jawaban atau nilai, yang kemudian digunakan untuk mengetahui pemahaman konsep siswa dalam menyelesaikan soal teorema Phytagoras. Teknik wawancara yang digunakan yaitu wawancara tidak terstruktur. Wawancara diberikan kepada 4 subjek yang terpilih yaitu 2 orang siswa bergaya kognitif Field Dependent (FD) dan 2 orang siswa bergaya kognitif Field Independent (FI) yang telah mengikuti tes tertulis soal teorema Phytagoras, dimana wawancara dilakukan secara satu persatu atau secara bergantian sehingga peneliti lebih mudah mendeskripsikan pemahaman konsep siswa dalam menyelesaikan setiap butir soal yang diberikan.

Selanjutnya, setelah data terkumpul maka dilakukan teknik analisis data. Analisis data GEFT dilakukan dengan cara mengidentifikasi gaya kognitif subjek Field Dependent (FD) dan Field Independent (FI) pada penelitian ini sebagai berikut (Lihat Tabel 3).

Tabel 3. Kriteria Pengelompokan Gaya Kognitif $F D$ dan FI.

\begin{tabular}{cc}
\hline Jenis Gaya Kognitif & Skor Siswa \\
\hline Field Independent $(\mathrm{FI})$ & $18 \geq x>9$ \\
Field Dependent $(\mathrm{FD})$ & $9 \geq x \geq 0$ \\
\hline & Sumber: Trinovita, 2017
\end{tabular}

Data hasil tes tertulis pemahaman konsep dianalisis dengan memberikan penilaian dan mendeskripsikan hasil jawaban sesuai dengan indikator pemahaman konsep. Data wawancara dianalisis menggunakan model Miles dan Huberman dengan tahapan reduksi data, penyajian data, dan penarikan kesimpulan.

\section{Hasil dan Pembahasan}

\section{Pemahaman Konsep Subjek Bergaya Kognitif Field Dependent (SFD)}

\section{a) Pemahaman Subjek Field Dependent (SFD) tentang Konsep Segitiga \\ - Menyatakan Ulang Sebuah Konsep}

Berdasarkan paparan data hasil tes S1FD dan S2FD tentang pemahaman konsep dalam menyatakan ulang sebuah konsep segitiga, menunjukkan bahwa kedua subjek S1FD dan S2FD mengenal bentuk gambar-gambar yang disajikan pada soal nomor 1 adalah 
segitiga. Selanjutnya, ditelusuri dari hasil wawancara kedua subjek S1FD dan S2FD mampu menyatakan ulang definisi segitiga dengan kata-katanya sendiri. Dari hasil analisis di atas, dapat disimpulkan bahwa kedua subjek S1FD dan S2FD mampu dalam menyatakan ulang definisi segitiga dengan kata-katanya sendiri.

\section{- Memberi Contoh dan bukan Contoh dari Konsep}

Berdasarkan paparan data hasil tes S1FD dan S2FD tentang pemahaman konsep dalam memberi contoh dan bukan contoh dari konsep segitiga, menunjukkan bahwa kedua subjek S1FD dan S2FD dapat menentukan dan membedakan bentuk gambar-gambar jenis segitiga yang disajikan. Selanjutnya, dari hasil wawancara subjek S1FD mampu memberikan contoh jenis segitiga dan memberikan contoh lain yang bukan jenis segitiga. Adapun, subjek S2FD tidak mampu memberikan contoh jenis segitiga dan yang bukan jenis segitiga.

Dari hasil analisis di atas, dapat disimpulkan bahwa subjek S1FD mampu membedakan contoh atau bukan contoh jenis segitiga, sedangkan subjek S2FD tidak mampu membedakan contoh atau bukan contoh jenis segitiga.

\section{b) Pemahaman Subjek Field Dependent (SFD) tentang Konsep Segitiga Siku-siku - Menyatakan Ulang Sebuah Konsep}

Berdasarkan paparan data hasil tes S1FD dan S2FD tentang pemahaman konsep dalam menyatakan ulang sebuah konsep segitiga siku-siku, menunjukkan bahwa kedua subjek S1FD dan S2FD mengenal bentuk gambar-gambar segitiga siku-siku. Subjek mampu memberikan alasan dengan menyatakan ulang definisi dan sifat-sifat segitiga sikusiku. Selanjutnya, dari hasil wawancara kedua subjek S1FD dan S2FD mampu menyatakan ulang definisi segitiga siku-siku dengan kata-katanya sendiri. Jadi kedua subjek S1FD dan S2FD mampu menyatakan ulang definisi segitiga siku-siku dengan kata-katanya sendiri.

\section{- Memberi Contoh dan bukan contoh dari Konsep}

Berdasarkan paparan data hasil tes S1FD dan S2FD tentang pemahaman konsep dalam memberi contoh dan bukan contoh dari konsep segitiga siku-siku, menunjukkan bahwa kedua subjek S1FD dan S2FD dapat menentukan gambar yang termasuk segitiga siku-siku dan yang bukan termasuk segitiga siku-siku dengan mengidentifikasi bentuk gambar segitiga yang disajikan pada soal nomor 1, mengidentifikasi definisi dan sifat-sifat dari konsep segitiga siku-siku yang terdapat pada soal nomor 1. Subjek menuliskan bangun segitiga siku-siku yaitu gambar a dan d, serta yang bukan merupakan segitiga siku-siku yaitu gambar b dan c. Selanjutnya, dari hasil wawancara kedua subjek S1FD dan S2FD 
dapat membedakan gambar-gambar segitiga yang disajikan yang mana termasuk segitiga siku-siku dan yang bukan termasuk segitiga siku-siku. Jadi kedua subjek S1FD dan S2FD dapat membedakan contoh atau bukan contoh dari segitiga siku-siku.

c) Pemahaman Subjek Field Dependent (SFD) tentang Konsep Sudut dan Sisi.

- Menyatakan Ulang Sebuah Konsep

Berdasarkan paparan data hasil tes S1FD dan S2FD tentang pemahaman konsep dalam menyatakan ulang sebuah konsep sudut dan sisi, menunjukkan bahwa kedua subjek S1FD dan S2FD menuliskan sudut dan sisi pada lembar jawabannya. Selanjutnya, dari hasil wawancara subjek S1FD mampu menyatakan ulang definisi sudut dengan katakatanya sendiri. Subjek S1FD mampu menunjukkan yang mana sudut siku-siku-nya pada soal nomor 1 bagian a, adapun subjek S2FD tidak mampu menyatakan ulang definisi sudut. Akan tetapi, mampu menunjukkan yang mana sudut siku-sikunya pada soal nomor 1 bagian d. Selanjutnya subjek S1FD dan S2FD tidak mampu menyatakan ulang definisi sisi, Akan tetapi, subjek S1FD mampu menunjukkan yang mana sisi-sisinya pada soal nomor 1 bagian a, begitupun dengan subjek S2FD tidak mampu menunjukkan yang mana sisi-sisinya pada soal nomor 1 bagian d. Jadi, subjek S1FD mampu menyatakan ulang definisi sudut dengan kata-katanya sendiri, sedangkan subjek S2FD tidak mampu menyatakan ulang definisi sudut dengan kata-katanya sendiri. Selain itu, kedua subjek S1FD dan S2FD tidak mampu menyatakan ulang definisi sisi.

\section{- Memberi Contoh dan bukan Contoh dari Konsep}

Berdasarkan paparan data hasil tes S1FD dan S2FD tentang pemahaman konsep dalam memberi contoh dan bukan contoh dari konsep sudut dan sisi, menunjukkan bahwa subjek S1FD dalam memberikan alasan segitiga siku-siku dan yang bukan segitiga sikusiku subjek menyebut sudut dan sisi-sisinya yang terdapat pada gambar terkait. Sedangkan, subjek S2FD menyebut sisi tegak lurus dan sudut siku-siku yang terdapat pada gambar a dan d. Selanjutnya, dari hasil wawancara subjek S1FD dan S2FD tidak mampu menyebutkan contoh dan bukan contoh dari sudut dan sisi. Maka disimpulkan bahwa kedua subjek S1FD dan S2FD tidak mampu dalam membedakan contoh atau bukan contoh dari sudut dan sisi.

\section{Pemahaman Konsep Subjek Bergaya Kognitif Field Independent (SFI)}

a. Pemahaman Subjek Field Independent (SFI) tentang Konsep Segitiga

- Menyatakan Ulang Sebuah Konsep

Berdasarkan paparan data hasil tes S1FI dan S2FI tentang pemahaman konsep 
dalam menyatakan ulang sebuah konsep segitiga, menunjukkan bahwa kedua subjek S1FI dan S2FI dapat mengenal bahwa gambar yang disajikan pada soal nomor 1 adalah gambar segitiga. Selanjutnya, dari hasil wawancara kedua subjek S1FI dan S2FI mampu menyatakan ulang definisi segitiga dengan kata-katanya sendiri. Maka dapat disimpulkan bahwa kedua subjek S1FI dan S2FI mampu dalam menyatakan ulang definisi segitiga dengan kata-katanya sendiri.

\section{- Memberi Contoh dan bukan Contoh dari Konsep}

Berdasarkan paparan data hasil tes S1FI dan S2FI tentang pemahaman konsep dalam memberi contoh dan bukan contoh dari konsep segitiga, menunjukkan bahwa kedua subjek S1FI dan S2FI dapat menentukan dan membedakan gambar-gambar segitiga yang disajikan. Selanjutnya, dari hasil wawancara dapat dilihat bahwa kedua subjek S1FI dan S2FI mampu memberikan contoh jenis segitiga dan memberikan contoh lain yang bukan jenis segitiga. Maka dapat disimpulkan bahwa kedua subjek S1FI dan S2FI mampu dalam membedakan contoh atau bukan contoh dari konsep segitiga.

\section{b. Pemahaman Subjek Field Independent (SFI) tentang Konsep Segitiga Siku-siku - Menyatakan Ulang Sebuah Konsep}

Berdasarkan paparan data hasil tes S1FI dan S2FI tentang pemahaman konsep dalam menyatakan ulang sebuah konsep segitiga siku-siku, menunjukkan bahwa kedua subjek S1FI dan S2FI mampu mengenal gambar segitiga siku-siku. Subjek S1FI dan S2FI mampu menyatakan definisi dan sifat-sifat segitiga siku-siku. Selanjutnya, dari hasil wawancara kedua subjek S1FI dan S2FI mampu menyatakan ulang definisi segitiga sikusiku dengan kata-katanya sendiri. Maka dapat disimpulkan bahwa kedua subjek S1FI dan S2FI mampu menyatakan ulang definisi segitiga siku-siku dengan kata-katanya sendiri.

\section{- Memberi Contoh dan Bukan Contoh dari Konsep}

Berdasarkan paparan data hasil tes S1FI dan S2FI tentang pemahaman konsep dalam memberi contoh dan bukan contoh dari konsep segitiga siku-siku, menunjukkan bahwa kedua subjek S1FI dan S2FI mampu menentukan gambar yang termasuk segitiga siku-siku dan yang bukan termasuk segitiga siku-siku dengan mengidentifikasi bentuk gambar segitiga yang disajikan pada soal nomor 1. Selanjutnya, dari hasil wawancara kedua subjek S1FI dan S2FI mampu membedakan gambar-gambar segitiga yang disajikan yang mana termasuk segitiga siku-siku dan yang bukan termasuk segitiga siku-siku. Maka dapat disimpulkan bahwa kedua subjek S1FI dan S2FI mampu membedakan contoh atau bukan contoh dari konsep segitiga siku-siku. 


\section{c. Pemahaman Subjek Field Independent (SFI) tentang Konsep Sudut dan Sisi - Menyatakan Ulang Sebuah Konsep}

Berdasarkan paparan data hasil tes S1FI dan S2FI tentang pemahaman konsep dalam menyatakan ulang sebuah konsep sudut dan sisi, menunjukkan bahwa kedua subjek S1FI dan S2FI menuliskan konsep sudut dan sisi pada lembar jawaban soal nomor 1. Selanjutnya, dari hasil wawancara dapat dilihat subjek S1FI tidak mampu menyatakan ulang definisi sudut dengan kata-katanya sendiri. Akan tetapi, subjek S1FI mampu menunjukkan yang mana sudut siku-sikunya. Subjek S1FI mampu menyatakan ulang definisi sisi dan mampu menunjukkan yang mana sisi-sisinya pada soal nomor 1 bagian a. Adapun subjek S2FI mampu menyatakan ulang definisi sudut dan sisi dengan kata-katanya sendiri. Subjek S2FI juga mampu menunjukkan yang mana sudutnya pada soal nomor 1 bagian d. Serta, subjek S2FI mampu menunjukkan yang mana sisi-sisinya pada soal nomor 1 bagian a. Maka dapat disimpulkan bahwa subjek S1FI tidak mampu dalam menyatakan ulang definisi sudut. Akan tetapi, subjek S1FI mampu dalam menyatakan ulang definisi sisi dengan kata-katanya sendiri. Adapun subjek S2FI mampu dalam menyatakan ulang definisi sudut dan sisi dengan kata-katanya sendiri.

\section{- Memberi Contoh dan bukan Contoh dari Konsep}

Berdasarkan paparan data hasil tes S1FI dan S2FI tentang pemahaman konsep dalam memberi contoh dan bukan contoh dari konsep sudut dan sisi, menunjukkan bahwa subjek S1FI dan S2FI menyebut sisi tegak lurus, sisi miring dan sudut $90^{\circ}$ yang terdapat pada gambar a dan d. Selanjutnya, dari hasil wawancara dilihat bahwa subjek S1FI dan S2FI tidak mampu menyebutkan contoh dan bukan contoh dari sudut. Maka dapat disimpulkan bahwa kedua subjek S1FI dan S2FI tidak mampu dalam membedakan contoh atau bukan contoh dari sudut.

\section{Kesimpulan}

Deskripsi pemahaman konsep subjek bergaya kognitif Field Dependent (SFD) dalam menyelesaikan soal teorema Phytagoras adalah

a) Pemahaman subjek Field Dependent (SFD) tentang konsep segitiga yaitu untuk indikator pertama, kedua subjek S1FD dan S2FD mampu dalam menyatakan ulang definisi segitiga dengan kata-katanya sendiri. Untuk indikator kedua, subjek S1FD mampu membedakan contoh atau bukan contoh jenis segitiga, adapun subjek S2FD tidak mampu membedakan contoh atau bukan contoh jenis segitiga. 
b) Pemahaman subjek Field Dependent (SFD) tentang konsep segitiga siku-siku yaitu untuk indikator pertama, kedua subjek S1FD dan S2FD mampu menyatakan ulang definisi segitiga siku-siku dengan kata-katanya sendiri. Untuk indikator kedua, kedua subjek S1FD dan S2FD dapat membedakan contoh atau bukan contoh dari segitiga sikusiku.

c) Pemahaman subjek Field Dependent (SFD) tentang konsep sudut dan sisi yaitu untuk indikator pertama, subjek S1FD mampu menyatakan ulang definisi sudut dengan katakatanya sendiri, sedangkan subjek S2FD tidak mampu menyatakan ulang definisi sudut dengan kata-katanya sendiri. Selain itu, kedua subjek S1FD dan S2FD tidak mampu menyatakan ulang definisi sisi. Untuk indikator kedua, kedua subjek S1FD dan S2FD tidak mampu dalam membedakan contoh atau bukan contoh dari sudut dan sisi.

Deskripsi pemahaman konsep subjek bergaya kognitif Field Independent (SFI) dalam menyelesaikan soal teorema Phytagoras adalah

a) Pemahaman subjek Field Independent (SFI) tentang konsep segitiga yaitu untuk indikator pertama, kedua subjek S1FI dan S2FI mampu dalam menyatakan ulang definisi segitiga dengan kata-katanya sendiri. Untuk indikator kedua, kedua subjek S1FI dan S2FI mampu dalam membedakan contoh atau bukan contoh dari konsep segitiga.

b) Pemahaman subjek Field Independent (SFI) tentang konsep segitiga siku-siku yaitu untuk indikator pertama, kedua subjek S1FI dan S2FI mampu menyatakan ulang definisi segitiga siku-siku dengan kata-katanya sendiri. Untuk indikator kedua, kedua subjek S1FI dan S2FI mampu membedakan contoh atau bukan contoh dari konsep segitiga siku-siku.

c) Pemahaman subjek Field Independent (SFI) tentang konsep sudut dan sisi yaitu untuk indikator pertama, subjek S1FI tidak mampu dalam menyatakan ulang definisi sudut. Akan tetapi, subjek S1FI mampu dalam menyatakan ulang definisi sisi dengan katakatanya sendiri. Adapun subjek S2FI mampu dalam menyatakan ulang definisi sudut dan sisi dengan kata-katanya sendiri. Untuk indikator kedua, kedua subjek S1FI dan S2FI tidak mampu dalam membedakan contoh atau bukan contoh dari sudut.

\section{DAFTAR PUSTAKA}

Herwandi. 2017. Analisis Pemahaman konsep dalam menyelesaikan Soal Geometri Dimensi Tiga pada Siswa Kelas XI SMK Muhammadiyah 2 Makassar. Skripsi tidak diterbitkan. Makassar: Universitas Muhammadiyah Makassar.

Kozhevnikov, M. 2006. Cognitive Styles in the Context of Modern Psychology: Toward an 
Integrated Framework of Cognitive Style. Psychological Bulletin, Vol. 133, No. 1.

Nurafni., Miatun, A. \& Khusna, H. 2018. Profil pemahaman konsep teorema phytagoras berdasarkan perbedaan gaya kognitif Field Independent dan Field Dependent. Jakarta: KALAMATIKA Jurnal Pendidikan Matematika, (Online), Volume 03, No. 02, hal. 175192. Universitas Muhammadiyah Prof. DR. HAMKA. (http://kalamatika.matematikauhamka.com, diakses pada tanggal 20 November 2019).

Sugiyono. 2018. Metode Penelitian Kuantitatif, Kualitatif dan R\&D. Bandung: Alfabeta.

Trinovita, E. 2017. Deskripsi kelancaran procedural dalam pemecahan masalah matematika ditinjau dari Gaya kognitif dan efikasi diri pada siswa kelas IX A SMP Negeri 5 Mandai. Skripsi tidak diterbitkan. Makassar: Universitas Negeri Makassar. 